\title{
Android Application-Based Basic Elements Model of Rhythmic Gymnastics
}

\author{
Christina Fajar Sriwahyuniati", Nella Novika Nuritasari, Ratna Budiarti, Endang Rini Sukamti \\ Faculty of Sport Sciences, Universitas Negeri Yogyakarta, Indonesia
}

Received October 10, 2021; Revised January 24, 2022; Accepted February 16, 2022

\section{Cite This Paper in the following Citation Styles}

(a): [1] Christina Fajar Sriwahyuniati, Nella Novika Nuritasari, Ratna Budiarti, Endang Rini Sukamti, "Android Application-Based Basic Elements Model of Rhythmic Gymnastics," International Journal of Human Movement and Sports Sciences, Vol. 10, No. 1, pp. 90 - 97, 2022. DOI: 10.13189/saj.2022.100113.

(b): Christina Fajar Sriwahyuniati, Nella Novika Nuritasari, Ratna Budiarti, Endang Rini Sukamti (2022). Android Application-Based Basic Elements Model of Rhythmic Gymnastics. International Journal of Human Movement and Sports Sciences, 10(1), 90 - 97. DOI: 10.13189/saj.2022.100113.

Copyright $\mathrm{C} 2022$ by authors, all rights reserved. Authors agree that this article remains permanently open access under the terms of the Creative Commons Attribution License 4.0 International License

\begin{abstract}
This research aims to develop a product in the form of an android application that can be used as a new method of learning and independent training for the basic elements of rhythmic gymnastics. The Research and Development method was used in this study. The research steps were adapted from Sugiyono's research steps which consisted of 13 steps, but the researchers only adapted 10 steps according to the research objectives. Small group

basic elements of android application based-rhythmic gymnastics. The product was made of several basic elements of rhythmic gymnastics motion pictures and videos (slow motion) supported by brief information, a brief history of gymnastics, videos of elite championships, athletes' achievements, and gym club contact support. The selection of motion elements was based on FIG's Code of points in 2017-2020.
\end{abstract} trials were conducted at Gymnastics Local Club on 8 children practicing rhythmic gymnastics, while the main field trials were carried out on 15 children practicing rhythmic gymnastics at local clubs. The research instruments were a scale questionnaire and evaluation sheets. Evaluation result data were in the form of descriptive quantitative and qualitative. Quantitative data were collected from assessments by means of a product trial questionnaire. Qualitative data were obtained through expert validation and trial activities in the form of input, feedback, criticism and suggestions. Quantitative data were analyzed using descriptive quantitative analysis. The results of the assessment obtained through expert validation and trials were processed in percentages. The percentage results were then elaborated using the qualitative method. The assessment for the feasibility aspect of the model of basic element of android application based-rhythmic gymnastics was seen from the results of the validation by material experts at $97.5 \%$ (strongly agree) and media experts at $96 \%$ (strongly agree). The results of the main field trial showed an assessment score at $98.16 \%$ (strongly agree). The product was a model of media for the
Keywords Android Application, Basic Techniques, Rhythmic Gymnastics

\section{Introduction}

Sports are purposeful physical activities that involve muscles and control done by humans. Sports are also games that accommodate the elements of nature, other people, or oneself and possess organizational complexity. Based on this definition there are three important elements that are interrelated and cannot be separated in sports. The three elements are physical activity, games, and organizational complexity. Physical activities in sports are intended as a physical activity that requires physical skills and not considered ordinary physical activity. Types of physical activities preferred by children are playing traditional games [1].

Socio-psychologically, sports can be considered as part of social institutions that exist in a society. This is 
reflected in the system, norms, rules of the game that are agreed. In addition to the system of rules, sports activities also involve the emotions of the people who take parts intensely. Also, there is a link between skills, cognition, attitudes, and values in sports.

According to Socrates, physical fitness is one the most important parts in all sports. People should try to maintain their physical condition because a healthy and strong physical can guarantee them to be consistent in living their life [2] particularly to support other aspects, such as technique, tactics, and mentality. Physical condition is very decisive to support the athlete's job in competition in order to perform optimally. A certain amount of flexibility is required for the success of all physical movements. Individual differences in physical condition and joint range of motion can mostly be caused by congenital, hereditary factors [3]. Training programs to keep physical conditions of the athletes must be well planned, be clear and be aimed at improving physical fitness to enable athletes to achieve better performance. Also, the level of physical fitness required on each sport is different. It must be adjusted according to the dominance of the biomotor and the required energy system [4].

In the era of disruption, the revolution of sports industry in Indonesia has become a necessity and a lifestyle for people in various community circles. Exercises are carried out as a step to gain physical fitness. The components of physical fitness are related to health (HRF; Namely, muscle strength/endurance and cardiorespiratory endurance [5]. Sport is essentially a miniature of life. This sentence implies that the basis of human daily activities can be found in sports activities. In principle, sports teach discipline, spirit, persistence and the spirit of cooperation. In Indonesia, sport is a national pride and is also a national program. The government has tried its best to promote sport to the social community. As the result, sports activities in Indonesia increase. People do sports for recreational, competitive and healthy purposes. There are many types of sports that can be chosen by the community according to their choices and needs. One of the sports that is quite popular with people in Indonesia in all age levels is gymnastics [6].

Gymnastics is a sport involving physical activities, like body movement, that prioritize flexibility. Gymnastics can be done either with or without music. In addition to health, gymnastics is also competed under the auspices of FIG [7]. According to [7] Gymnastics are meaningful and purposeful activities. This is in accordance with the progress and development of the sport and the goals to be achieved through it.

Gymnastics requires certain body posture, quality of movement, and coordination with the apparatus when it comes to competitions. The gymnast must also integrate their motor control, balance, and strength [8]. Body exercises are selected and created deliberately and planned, systematically arranged with the aim of forming and developing a person in harmony. It is also said that "gymnastics can be defined as a form of body exercise on the floor using a device designed to increase endurance, strength, flexibility, agility, coordination, and body control of the athletes. This also helps the athletes to develop their control of body flexibility, explosive leg strength and coordination, which are the most significant determinants of success in rhythmic gymnastics. Therefore, these findings are very important in relation to sorting the gymnastics types as desired [9]. In Indonesia, gymnastics are legally contested. The competed gymnastics branches are rhythmic gymnastics, men's artistic gymnastics, women's artistic gymnastics, and aerobics. In this study, researchers focused on rhythmic gymnastics, a gymnastic movement performed to the rhythm of music, or free exercises performed rhythmically. Rhythmic gymnastics has become a type of sports experiencing constant evolution because it is permanent. This claim is based on the analysis of the factors that influence it [10].

Rhythmic gymnastics is a sport branch that displays basic ballet-like movements and requires body flexibility to create a perfect combination of art and sports, especially where one or a group of gymnasts manipulates the skills of gymnastic equipment. Rhythmic gymnastics requires body and physical control to display great quality motion (Mirela, Raducu, Antoanela, Carmen \& Laura, 2014 [11]. In rhythmic gymnastics, it is important to train body skills and equipment skills separately. Warm-up is an ideal time to introduce and train the body skills where the athletes prior to using the equipment [12]. Some of the equipment used in gymnastics are ropes, hoops, balls, clubs and ribbons. The program for Senior and Junior individual gymnasts usually consists of 4 exercises (see Fig Apparatus Program for Seniors and Juniors in Annex) Rope (except Individual Seniors) Hoop Ball Clubs Ribbon [13]. There are several elements that the athletes should master, namely jumps, spins and swings balance, and also tool mastery skills in throwing and catching tools. Also, mastery in expression on movements, instruments and music is also essential. In a series of rhythmic gymnastics, athletes must perform movements according to the requirements and rules contained in FIG [7], namely: difficulty, mastery (AD), throw (R) and dance step. The series is carried out with musical accompaniment which lasts one and a half minutes. In the rhythmic gymnastics competition, there are several judges who will judge the entire series of movements of the gymnastics athletes, with the rules written in FIG [7], namely: difficulty jury (D), execution jury (E), line jury, timer, and secretary who will assess according to their respective duties. In a rhythmic gymnastics competition, each athlete must perform a series of rhythmic gymnastics movements in five tools, namely hoops, balls, maces, ropes and ribbons individually.

The development of gymnastics, especially in Special Region of Yogyakarta (DIY) province is still considered below-par in terms of achievement, facilities and 
infrastructure. This is proven when the athletes joined local competitions. The achievement is not satisfying. Also, when joining the national competitions, the athletes' achievement is no better, meaning that the gymnastics training quality of DIY province is still far from being perfect. One of the contributing factors to these unsatisfying conditions is the lack of coaching and facilities that are suitable for the athletes. The Special Region of Yogyakarta is a relatively small province with 5 districts. Unfortunately, of the 5 regencies there are only 3 districts that are consistently taking part in consistent in gymnastics championship, namely Yogyakarta city, Sleman regency, and Bantul regency. The other 2 districts, Kulonprogo and Gunung Kidul regency are participating in local competitions only [14].

Selabora or sports laboratory school is a local club established to manage sports coaching in collaboration with local university [14]. In this sport laboratory, there are 3 types of gymnastics that are managed, namely: artistic gymnastics (male and female athletes), rhythmic gymnastics and aerobics. The process of rhythmic gymnastics training at Selabora is mostly carried out in the training ground. Unfortunately, when the training is in progress, there will be some children suddenly join the training, which may cause disruptions. They can be involved in the training, but they must be treated differently. For example, the training process for young children or beginners currently joining the club will be different from children who have been practicing for considerably longer time. During the training program, the newcomers will practice basic movements in rhythmic gymnastics such as flexibility, jumping, rotation and balance. The whole training process will be conducted 3-4 times a week. However, some children can only come 1 or 2 times a week, which means that those children will need to spend 2-3 months to master one element of the movements properly.

One of the obstacles to overcome is dealing with the regularity of the training program. The younger athletes (the children) are still unable to regularly attend the training program. This makes the training process ineffective. As the result, such lack of practice will hinder the development of children's abilities. To come up with, it is necessary to carry out independent exercises at home. Unfortunately, doing exercises at home leads to another new problem. The learning resources or media that can be used as models are still insufficient. It is hoped that the android application that researchers are developing will enable the children to practice independently at home by looking at the guidelines available in the application. Training the basics skills such as jumping, rotating and balancing in rhythmic gymnastics will require a long time to be mastered. Through this application, it is expected that the children will be able to perform movements well and accurately. This can be concluded from a preliminary study conducted by the researchers in order to obtain the fact that there is no android-based application by performing basic rhythmic gymnastics techniques particularly to train the aforementioned basic skills. That is why this research is very important for trainers. In addition, gymnastics videos available on YouTube and other android applications do not explain the training process to develop basic element models of rhythmic gymnastics with clear motion techniques. The basic element model of rhythmic gymnastics is a game consisting of several disciplines [15].

In addition to this, the videos on YouTube or other platforms do not meet the criteria in accordance with the rules made by FIG yet. Therefore, the researcher chose to make an application about the basic element model of rhythmic gymnastics based on an android application, which contains basic motion techniques in order to help early age gymnasts and beginners to practice basic techniques with clear motion techniques, to meet the goal of this study. It is also found that there are no previous studies to discuss this topic [15]. Early age is considered the right period to develop children's abilities, while the elementary school period is the key period for the development of basic skills and advanced movement skills [16] particularly to form flexibility and good movements of balancing, jumping and spinning. This period is also a period of brain development as the center of consciousness. The sensory organs and organs of balance are developing rapidly as well. The training process to be carried out must also be gradual, and takes sufficient time particularly to seek for athletes to be. Sports coaching starting from an early age is also the right way to produce young athletes. It is also necessary to measure performance specifically for sports to determine progress and skill potentials of them [17].

\section{Materials and Methods}

\subsection{Research Methods}

This research is a research and development. Research and Development approach is a research method used to produce certain products to meet the effectiveness of these products [18]. As the result, this type of research is considered as a learning process that aims to develop new products or improve products used in the learning and training process. In addition, research and development consists of a set of processes or steps to develop a new product or improve an existing product, which can be accounted for. Development research is product-oriented research.

Based on the design of this study, the researcher aimed to create a learning media in the form of an application to develop a model of the basic elements of rhythmic gymnastics; rotation, jump, and balance. There are several stages of elemental movement exercises in rhythmic gymnastics of jumps, rotations, and balance to be put in the application. The exercises are equipped with the name of the movement and its implementation. Based on the 
needs analysis, the development stage of this research is carried out to create products in the form of basic rhythmic gymnastics techniques compiled in the form of an android application.

In the design of this study, the researcher wanted to create a learning media in the form of an application to develop a model of the basic elements of rhythmic gymnastics rotation, jump, and balance. In the application there are several stages of elemental movement exercises in rhythmic gymnastics of jumps, rotations, and balance exercises that are equipped with the name of the movement and its implementation. Based on needs analysis, development is carried out to produce products in the form of basic rhythmic gymnastics techniques compiled in the form of an android application.

\subsection{Research Settings}

The research was conducted at a local club in the Special area of Yogyakarta. The research was carried out on August 1, 2020 to September 15, 2020, during the afternoon practice at $16.00 \mathrm{WIB}$ and on several different days.

\subsection{Research Subjects}

This research was conducted to finalize the independent training model by practicing it directly. Meanwhile, the small-scale trial subjects were 8 athletes, and the large-scale trial subjects were 15 athletes.

The research subjects using the application are coaches and athletes who train at the local club, the special area of Yogyakarta. The technique of determining the test subjects in this development research is the purposive sampling method. Purposive sampling is a sampling technique of data sources in reference to certain considerations [18]. The considerations used are children who have recently joined or are still beginners in the Gymnastics Collaboration Club, especially rhythmic gymnastics.

\subsection{Data Collection Techniques and Instruments}

The data were collected by conducting surveys and field studies at the local club in the Special Region of Yogyakarta to find out what factors underlie the occurrence of the problem. In addition, the researchers collected the materials needed by referring to books, journals, theses and discussions.

\subsubsection{Interview}

The first data collection technique used was direct interviews with gymnastics coaches and athletes. The researcher conducted interview to obtain in-depth information about the obstacles and shortcomings that exist in the training period.

\subsubsection{Observation}

The data were also collected through observation and recording. The advantage of using the observation method is that there are a lot of information that can only be investigated effectively through observations.

\subsubsection{Questionnaires}

Questionnaires are a set of data collection tool that contains a number of statements that must be answered by the research subject.

The model development instruments in this study were grouped into two, namely: product validation and field trials. In product validation stage, product drafts are given to material and media experts to get input and recommendations. The validation sheet is also used to obtain an assessment of the feasibility of the Android Application-Based Basic Elements Model of Rhythmic Gymnastics. For the material and media expert validation, questionnaire sheets using a Likert scale are administered. Likert scale is used to measure attitudes, opinions and perceptions of a person or group of people about social phenomena [18]. In this case, the researcher divided the assessment categories in the questionnaire with the form of answers "Strongly Agree", "Agree", "Disagree", and "Strongly Disagree".

\subsection{Data Analysis Techniques}

The types of data collected in this media development are in the form of quantitative and qualitative data. Qualitative data obtained from the assessment of the quality of media products can be used to refine the product quality. Meanwhile, the quantitative data obtained from the questionnaires are filled out by material experts, media experts, and the users (children) are also benefited to enrich the data of the research [18]. The instrument to collect data in this development research is a set of questionnaires. The formula used in this development research is as follows:

Percentage $=$ Total Score obtained X 100\%: Total score

\section{Result and Discussion}

Based on the numerical analysis in the form of percentage of the questionnaires, the data can be classified as follows:

Table 1. Score Conversion Guide

\begin{tabular}{|c|c|}
\hline Achievement Percentage & Interpretation \\
\hline $76-100 \%$ & Strongly Agree \\
\hline $51-75 \%$ & Agree \\
\hline $26-50 \%$ & Disagree \\
\hline $0-25 \%$ & Strongly Disagree \\
\hline
\end{tabular}

From the table above, it is known about the data classification criteria for filling out the questionnaire. After the data is analyzed the percentage. Furthermore, the interpretation of the data is determined based on the criteria norms in table 1 . 


\section{Discussion}

The development of the Basic Elements Model of Rhythmic Gymnastics Based on Android Applications has been developed and validated by Experts and material experts. The preparation of this product development was conducted through several stages of research and development. The first preparation step of the Basic Elements Model of Rhythmic Gymnastics Based on this Android Application development was looking for relevant results as a reference for researchers [19,20,21,22] and looking for related references. Previous studies from Irani Trisnanda, developing basic rhythmic gymnastics techniques based on audio-visual freehand circuits for children aged 7-11 years, the results are very suitable so that they become the basis for developing android applications so that children will be helped in training and not dependent on coaches so that from existing applications the child can learn on their own. Studies from Agus Prestianto with the title development of stop motion learning media software Floor gymnastics techniques on
Android-based smartphones from this previous research, the idea emerged to develop rhythmic gymnastics using applications. Meanwhile, Endang Murti's research on the Development of Early Age Talent Guiding Tests in the Sportive Rhythmic Gymnastics Branch became the basis for developing so that before they learn and do exercises there is an application that helps to practice. In addition, several studies related to the use of technology in rhythmic gymnastics $[23,24]$ show that the use of technology in the implementation of exercises and assessments in rhythmic gymnastics greatly helps the effectiveness and efficiency of exercise implementation and performance assessment. A follow-up to the research that has been done is to conduct research on the effect of exercise using applications on mastery of skills Basic techniques of rhythmic gymnastics. Then, the researcher made an initial draft. The draft was then revised to accommodate the suggestions and input from material experts and media experts on the initial product. The results of product quality based on small-scale try out can be seen in table 2 .

Table 2. The product quality based on small-scale try out

\begin{tabular}{|c|c|c|c|c|}
\hline No & Assessment Criteria & Mean & Percentage & Criteria \\
\hline 1 & The image and video resolutions are high & 4.0 & $100.00 \%$ & Strongly Agree \\
\hline 2 & The file size is sufficient & 4.0 & $100.00 \%$ & Strongly Agree \\
\hline 3 & The application is easy to operate & 4.0 & $100.00 \%$ & Strongly Agree \\
\hline 4 & The instructions are easy to understand & 3.8 & $93.75 \%$ & Strongly Agree \\
\hline 5 & The theme, designs, pictures and videos are interesting & 3.6 & $90.63 \%$ & Strongly Agree \\
\hline 6 & The interface is clear & 3.9 & $96.88 \%$ & Strongly Agree \\
\hline 7 & The background color is suitable & 3.6 & $90.63 \%$ & Strongly Agree \\
\hline 8 & The font types and size are appropriate & 3.5 & $87.50 \%$ & Strongly Agree \\
\hline 9 & The color combination of the interface is appropriate. & 3.8 & $93.75 \%$ & Strongly Agree \\
\hline 10 & The materials included are aimed at independent learning. & 3.9 & $96.88 \%$ & Strongly Agree \\
\hline 11 & $\begin{array}{l}\text { Images and videos included in the application represents the basic elements of } \\
\text { rhythmic gymnastics. }\end{array}$ & 3.8 & $93.75 \%$ & Strongly Agree \\
\hline 12 & $\begin{array}{l}\text { The naming of movement elements are in accordance with the code of point of } \\
\text { rhythmic gymnastics. }\end{array}$ & 4.0 & $100 \%$ & Strongly Agree \\
\hline 13 & $\begin{array}{l}\text { The procedures included are in accordance with basic elements of rhythmic } \\
\text { gymnastics theories. }\end{array}$ & 3.8 & $93.75 \%$ & Strongly Agree \\
\hline 14 & The languages used are easy to understand. & 4.0 & $100.00 \%$ & Strongly Agree \\
\hline 15 & The operational languages are appropriate. & 3.6 & $90.63 \%$ & Strongly Agree \\
\hline 16 & The interface at the beginning of the application is appropriate. & 4.0 & $100.00 \%$ & Strongly Agree \\
\hline 17 & The images and videos included are in accordance with the use. & 3.9 & $96.88 \%$ & Strongly Agree \\
\hline 18 & The instructions available can help the users using the application. & 3.9 & $96.88 \%$ & Strongly Agree \\
\hline 19 & The application is simple as it is android-based. & 4.0 & $100.00 \%$ & Strongly Agree \\
\hline 20 & The operation of the application is easy. & 4.0 & $100.00 \%$ & Strongly Agree \\
\hline \multicolumn{2}{|c|}{ Total Score } & 76.9 & - & \multirow{2}{*}{ Strongly Agree } \\
\hline \multicolumn{2}{|c|}{ Mean } & 3.8 & $96.09 \%$ & \\
\hline
\end{tabular}


Table 3. The questionnaire results on big scale try out

\begin{tabular}{|c|c|c|c|c|}
\hline No & Assessment Criteria & Mean & Percentage & Criteria \\
\hline 1 & The image and video resolutions are high & 4.0 & $100 \%$ & Strongly Agree \\
\hline 2 & The file size is sufficient & 4.0 & $100 \%$ & Strongly Agree \\
\hline 3 & The application is easy to operate & 4.0 & $100 \%$ & Strongly Agree \\
\hline 4 & The instructions are easy to understand & 3.8 & $100 \%$ & Strongly Agree \\
\hline 5 & The theme, designs, pictures and videos are interesting & 3.8 & $95 \%$ & Strongly Agree \\
\hline 6 & The interface is clear & 3.9 & $98.33 \%$ & Strongly Agree \\
\hline 7 & The background color is suitable & 3.8 & $95 \%$ & Strongly Agree \\
\hline 8 & The font types and size are appropriate & 3.9 & $96.67 \%$ & Strongly Agree \\
\hline 9 & The color combination of the interface is appropriate. & 3.8 & $95 \%$ & Strongly Agree \\
\hline 10 & The materials included are aimed at independent learning. & 4.0 & $100 \%$ & Strongly Agree \\
\hline 11 & $\begin{array}{l}\text { Images and videos included in the application represents the basic elements of } \\
\text { rhythmic gymnastics. }\end{array}$ & 4.0 & $100 \%$ & Strongly Agree \\
\hline 12 & $\begin{array}{l}\text { The naming of movement elements are in accordance with the code of point of } \\
\text { rhythmic gymnastics. }\end{array}$ & 4.0 & $100 \%$ & Strongly Agree \\
\hline 13 & $\begin{array}{l}\text { The procedures included are in accordance with basic elements of rhythmic } \\
\text { gymnastics theories. }\end{array}$ & 4.0 & $100 \%$ & Strongly Agree \\
\hline 14 & The languages used are easy to understand. & 4.0 & $100 \%$ & Strongly Agree \\
\hline 15 & The operational languages are appropriate. & 3.9 & $98.33 \%$ & Strongly Agree \\
\hline 16 & The interface at the beginning of the application is appropriate. & 3.7 & $91.67 \%$ & Strongly Agree \\
\hline 17 & The images and videos included are $3.8 \mathrm{in}$ accordance wit $3.9 \mathrm{~h}$ the use. & 4.0 & $100 \%$ & Strongly Agree \\
\hline 18 & The instructions available can help the users using the application. & 3.9 & $98.33 \%$ & Strongly Agree \\
\hline 19 & The application is simple as it is android-based. & 4.0 & $100 \%$ & Strongly Agree \\
\hline 20 & The operation of the application is easy. & 4.0 & $100 \%$ & Strongly Agree \\
\hline \multicolumn{2}{|c|}{ Total Score } & 78.5 & - & \multirow{2}{*}{ Strongly Agree } \\
\hline \multicolumn{2}{|c|}{ Mean } & 3.9 & $98.42 \%$ & \\
\hline
\end{tabular}

The assessment on "Basic Elements Model of Rhythmic Gymnastics Based on this Android Application" was 3.7, or $92.81 \%$ classified as strongly agree.

The results of questionnaire results on big scale try out can be seen in table 3 . The main data obtained from the try out process, especially about the quality of the learning media product gained the score of 3.7 , or, $94.58 \%$ which means that this learning product (media) is considered strongly agree. This further means that the quality of the product is very good.

There are several suggestions given by the media experts, such as:

a The trainer's profile must be included

b Important note part must be included in the practice part

c The video slows motion must be slower

d The profile and achievement of the athletes must be included.

e The history of gymnastics part must be added.

f Researchers' expertise data must be included

$\mathrm{g}$ The profile of each element must be adjusted in accordance with each target movement

$\mathrm{h} \quad$ Specific directions must be included

i Attracting videos must be included

\section{j The developers' profile must be included}

There are also suggestions given by materials experts:

a The materials should be classified into factors

b The materials on elements must be more specific

c Additional videos on rhythmic gymnastics must be included

The feedbacks (inputs) and suggestions from media and material experts are accommodated to improve the initial product before being tested on small-scale research subjects. This development process goes through research and development procedures, consisting of planning, production and evaluation stages. When the initial draft has been validated by media experts and materials experts, an initial product draft is prepared. Then, the initial product of the Android Application-Based Rhythmic Gymnastics Basic Element Model will also be validated by media experts and material experts. The results of the validation by experts were declared feasible with a slight revision and continued for small group trials. Experts' validation was carried out once only. The small group trial was carried out on September 2, 2020 at 16.00 WIB during a local gymnastics club exercise in DIY with 8 trainees as respondents. The assessment of "Model Elements of 
Rhythmic Gymnastics Based on Android Applications" gain the score of 3.7 or $92.81 \%$ which is included in the "Strongly Agree" criteria. Based on the inputs for the small-scale research, the application was then declared eligible to continue to large-scale trials. Given the fact that the result of small group trial of the Basic Elements Model of Rhythmic Gymnastics Based on the Android Application was considered in "Strongly Agree" category, then trial was carried out in a large group trial on September 6, 2020 at 16.00 WIB during gymnastics practice in Antic Bantul. Respondents in the trial were 15 trained children. The data obtained from the main field trials in the aforementioned table regarding the quality of learning media products obtained an average score of 3.7 with a percentage of $94.58 \%$ which means that this learning media product is classified as "Strongly Agree".

There are several advantages can be beneficiary by using this product. Firstly, the training model is packaged in a simple, more optimal and attractive way in delivering material so that the trainers and the athletes can enjoy interesting and fun learning exercises through android-based applications [16]. Secondly, the existing videos are also equipped with slow motion movements and there are stages of the procedure on how to move so that it is easier for them to learn. Finally, this android application is considered more effective than existing learning media because this application is also equipped with a manual that makes it easy for beginners or users to understand every movement. There is also a brief history of gymnastics and elite video that aims to motivate users to be more active and enthusiastic in doing the practices in order to gain maximum achievement.

The weaknesses of this product are: children always find it difficult to use the applications by themselves, so they need to be accompanied by the parents. Another weakness is that good internet reception is needed to operate the application to ensure the stability of watching video materials. Lastly, the weakness of this application is that the elements presented in this android application do not include all element movements with a value of 0.1 .

The limitations of the research existing the process of this research are:

1. Athletes do not immediately master the basic element movements given so that it requires time and direction from the coach for athletes to perform movements properly and correctly.

2. In the process of taking pictures and videos, researchers also found problems particularly when the athlete made the movement of the elements the recording process do not capture the movement as done by the athletes.

3. The process of editing images and videos is time-consuming. The process of developing this android-based application also takes a long time to complete from the planning stage to the final product.
4. Small group and large group trial data collection is limited due to the COVID-19 pandemic.

\section{Conclusions}

Based on the results of the research on the development of the feasibility assessment of the product "Model Elements of Rhythmic Gymnastics Based on Android Applications" it can be concluded that based on the results of validation by material experts 1 and 2 this product obtained a percentage of $97.5 \%$ classified as "strongly agree" criteria. Meanwhile, according to the assessment form media expert 1 , this product obtained a percentage of $96.66 \%$, and the assessment from media expert 2 , this product obtained a percentage of $95 \%$, both of which were in the criteria of "strongly agree". Moreover, based on the athlete's assessment in the field trial, the criteria were classified "strongly agree" with a percentage of $98,16 \%$. The result of this development product is a media model of the basic elements of rhythmic gymnastics based on an android application that is useful for the training process independently. This product is composed of several basic elements of rhythmic gymnastics consisting of rotation, jumping, and balance. The selection of basic movements is based on the 2017-2020 Code of points from the FIG (Federation Internationale de Gymnastique). To be able to support the achievement of rhythmic gymnastics performance, further research can be carried out on the development of technology-based advanced rhythmic gymnastics.

\section{Acknowledgments}

We are very grateful to experts for their appropriate and constructive suggestions to improve this template.

\section{REFERENCES}

[1] W. S. Suherman, Dapan, Guntur, and N. R. Muktiani, "Development of traditional children play based instructional model to optimize development of kindergarteners' fundamental motor skill," Cakrawala Pendidik., vol. 38, no. 2, pp. 356-365, 2019, doi: $10.21831 /$ cp.v38i2.25289.

[2] P. Sutapa et al., "Motor Development Index (MDI) Based on Combination of Human Development Index (HDI) and Sport Development Index (SDI) as a Success Parameter of Motor Development among Preschool Children: An Observational Study," J. Phys. Conf. Ser., vol. 1529, no. 3, 2020, doi: 10.1088/1742-6596/1529/3/032003.

[3] J. Ylinen, Stretching therapy: for sport and manual therapies, no. July. 2008.

[4] Tomoliyus, Strategi Pembinaan Kondisi Fisik Untuk 
Mencapai Prestasi Olahraga Optimal. Yogyakarta: FIK UNY, 2019.

[5] D. F. Stodden, J. D. Goodway, and S. J. Langendorfer, "and Health-Related Fitness in Youth," Pediatr. Exerc. Sci., no. 26, pp. 231-241, 2014.

[6] E. R. Sukamti, Peranan Kodisi Fisik Untuk Pesenam. Yogyakarta: FIK UNY, 2019.

[7] F. I. de G. FIG, "2017 - 2020 Code of Points Women' s Artistic Gymnastics," FIG Exec. Comm., no. November 2017, 2017.

[8] H. Root, A. N. Marshall, A. Thatcher, A. R. Snyder Valier, T. C. Valovich McLeod, and R. Curtis Bay, "Sport specialization and fitness and functional task performance among youth competitive gymnasts," J. Athl. Train., vol. 54, no. 10 , pp. 1095-1104, 2019, doi: 10.4085/1062-6050-397 -18 .

[9] J. Radaš, M. Ukić, and G. F. Mandić, "Model values of motor abilities of junior rhythmic gymnasts in the Republic of Croatia," Kinesiology, vol. 51, no. 2, pp. 219-226, 2019, doi: 10.26582/k.51.2.11

[10] C. Leandro, "Success in rhytmic gymnastics competition:study of evaluation and performance variables in individual routines," 2017, [Online]. Available: http://www.tesisenred.net/handle/10803/404831.

[11] B. R. Agostini, E. M. D. G. Palomares, R. D. A. Andrade, F. N. M. Uchôa, and N. Alves, "Analysis of the influence of plyometric training in improving the performance of athletes in rhythmic gymnastics," Motricidade, vol. 13, no. 2, pp. 71-80, 2017, doi: 10.6063/motricidade.9770.

[12] S. Olympics, "Teaching Rhythmic Gymnastics Skills."

[13] FIG (Fédération Internationale de Gymnastique), "2017 2020 Code of Points - Trampoline Gymnastics," Br. Gymnast., no. July 2019, p. 85, 2019, [Online]. Available: https://www.gymnastics.sport/publicdir/rules/files/en_TR A CoP 2017-2020.pdf.

[14] Trisnanda, "PENGEMBANGAN TEKNIK GERAK DASAR SENAM RITMIK RANGKAIAN FREEHAND
BERBASIS AUDIOVISUAL UNTUK ANAK USIA 7-11 TAHUN," Universitas Negeri Yogyakarta, 2018.

[15] E. R. Sukamti, R. Budiarti, and R. Nurfadhila, "Effect of physical conditioning on student basic skills gymnastics," Cakrawala Pendidik., vol. 39, no. 1, pp. 207-216, 2020, doi: 10.21831/cp.v39i1.29641.

[16] S. J. Lin and S. C. Yang, "The norm of fundamental movement skills for children aged three to seven," Int. J. Hum. Mov. Sport. Sci., vol. 8, no. 4, pp. 134-141, 2020, doi: 10.13189/saj.2020.080405.

[17] J. K. Dunlavy et al., "Strength performance assessment in a simulated men's gymnastics still rings cross," J. Sport. Sci. Med., vol. 6, no. 1, pp. 93-97, 2007.

[18] Sugiyono, Metode penelitian kuantitatif, kualitatif, $R \& D$. Bandung: PT. Alfabeta, 2015.

[19] Prestianto Agus. Pengembangan Sofware Media Pembelajaran "Stop Motion Teknik Senam Lantai Pada Smartphone Berbasis Android”. Skripsi: FIK PKO UNY. Yogyakarta, 2017.https://id.wikipedia.org/wiki/Ponsel_cer das

[20] Trisnanda Irani. Pengembangan Teknik Gerak Dasar Senam Ritmik Rangkaian Freehand Berbasis Audiovisual Untuk Anak Usia 7-11 Tahun. Skripsi FIK PKO UNY. Yogyakarta. 2018.

[21] Sulistyowati Endang Murti. Pengembangan Tes Pemanduan Bakat Usia Dini Pada Cabang Olahraga Senam Ritmik Sportif. Tesis FIK UNY. Yogyakarta. 2020.

[22] Oktaviana, I., Soegiyanto, S., \& Rifai, A. Information Technology-Based Assessment Development Model for Rhythmic Gymnastics Referees in Semarang City. Journal of Physical Education and Sports, 9(1), 76-80, 2020. Retrieved from https://journal.unnes.ac.id/sju/index.php/jp es/article/view/37533

[23] Youguo Shi; Shuqin Chen; Haitao Wang. Mobile Multimedia Classroom Construction for Rhythmic Gymnastics Based on APT Teaching Model. nternational Journal of Emerging Technologies in Learning. Vol. 12 Issue 7, p79-89, 2017. 